\title{
Fiscal Policy and the Composition of Private Consumption: Some Evidence from the U.S. and Canada
}

\author{
Jim Malley \\ University of Glasgow
}

and

Hassan Molana

University of Dundee

March 1998

\begin{abstract}
This paper develops a generalised version of the life-cycle model in which consumers' preferences are defined over components of consumption and are affected by the level of public expenditure on goods and services. The model implies that the crowding out of private consumption could in fact be a direct demand side phenomenon caused by the way preferences respond to a change in public spending. Evidence from the U.S. and Canadian data for the period 1935-1995 confirms this theoretical conjecture as well as implying that in both countries demand for durable goods is likely to show relatively large swings which may undermine the stability of the sector and harm the supply side.
\end{abstract}

\section{JEL Classification: E22, E62}

Jim Malley: $\quad$ Department of Economics, University of Glasgow, Glasgow G12 8RT, UK.

Tel: 0141-3304617, E-mail: j.malley@ socsci.gla.ac.uk

Hassan Molana: Department of Economic Studies, University of Dundee, Dundee DD1 4HN, UK.

Tel: 01382-344375, E-mail: h.h.molana@dundee.ac.uk 


\section{Introduction}

The importance of quantifying the response of consumers' expenditure on goods and services to a change in public expenditure has motivated many attempts by economists to specify the relationship between public and private consumption. In most cases, however, these attempts are focused on measuring the overall impact of a public expansion - and its financing - on private consumption ${ }^{1}$ and very little effort is made to unravel the reallocative effects which amount to a change in the composition of private consumption. It is nevertheless important for policy makers to have some measure of the way fiscal policy affects private expenditure on goods and services as well as knowing whether or not it changes the shares of various categories of expenditure. The relevance of the latter becomes even clearer if we note the extreme case in which aggregate private consumption remains unaffected by a change in public consumption due to changes in components of private consumption cancelling out. In this case, the conclusion about the impact of the policy will have to be confined to its redistributive effects. Because such a reallocation in demand for goods and services is likely to have severe consequences for the level of output and employment at the micro/industry level, policy makers should be made aware of them $a$ priori.

In this paper we attempt to quantify the way major components of aggregate consumption, that is durable and nondurable goods and services consumption, respond to a change in public spending. The theoretical relationship is derived by solving a life-cycle utility maximisation model in which consumers' preferences are defined over components of consumption as well as being affected by the level of public expenditure. We use this framework to illustrate that the crowding out of private consumption could in fact be a direct

\footnotetext{
${ }^{1}$ See, for example, Aschauer (1985) and for more recent studies Ni (1995) and Darby and Malley (1996).
} 
demand side phenomenon caused by the way preferences respond to a change in public spending. The model is then estimated using the time series data for the U.S. and Canada and simulations, based on a shock to public spending, are used to calculate how each component is affected. The results show that in both countries the response of durable consumption is very different from the way consumers' expenditure on nondurable goods and services reacts to the shock. They also show that there is a remarkable difference in the way the private sector in the two countries react to a fiscal shock.

The rest of the paper is divided into three sections. Section 2 outlines the theory, Section 3 presents and discusses the evidence for the U.S. and Canada respectively, and Section 4 concludes the paper.

\section{Theory}

The theoretical framework used in this paper is similar to what is now known as the "consolidated life-cycle approach" which is a formalisation of the approach adopted by the earlier studies of the Ricardian Neutrality hypothesis ${ }^{2}$. The representative consumer's lifetime utility is given by a time separable function,

$$
U_{t}=\sum_{j=0}^{\infty}(1+\theta)^{-j} u\left(C_{t+j}, S_{t+j} ; G_{t+j}\right)
$$

where $\theta$ is the subjective rate of time preference and $u(C, S ; G)$ denotes a well behaved function summarising how preferences are (i) defined over consumption of nondurable goods and services and the services from durable goods, $C$ and $S$, and (ii) affected by the level of public spending on goods and services, $G$. The constraints facing the consumer are

$$
W_{t+j}=\left(1+r_{t+j}\right) W_{t+j-l}+\left(X_{t+j}-T_{t+j}\right)-\left(q_{c, t+j} C_{t+j}+q_{d, t+j} D_{t+j}\right),
$$

\footnotetext{
${ }^{2}$ See for example, Feldstein (1982), Kormendi (1983), Aschauer (1985) and Modigliani and Sterling (1986).
} 


$$
\begin{aligned}
& S_{t+j}=\left(1-\delta_{t+j}\right) S_{t+j-1}+D_{t+j}, \\
& B_{t+j}=\left(1+r_{t+j}\right) B_{t+j-l}+\left(q_{g, t+j} G_{t+j}-T_{t+j}\right),
\end{aligned}
$$

and

$$
W_{t+j}=A_{t+j}+B_{t+j} .
$$

Equation (2) is the consumers' intertemporal budget constraint which shows how financial wealth $W$ evolves; $X$ is income from employment, $T$ is net transfers from the private to the public sector, and $C$ and $D$ denote expenditure on non-durable goods and services and durable goods respectively. All variables are measured in real terms using the income deflator, $P$ and $q_{c}$ and $q_{d}$ are the relative prices of $C$ and $D$, defined as follows

$$
\begin{aligned}
& q_{c, t+j}=P_{c, t+j} / P_{t+j}, \\
& q_{d, t+j}=P_{d, t+j} / P_{t+j},
\end{aligned}
$$

and $r$ is the real interest rate which is related to the nominal interest rate, $n$, as follows

$$
1+r_{t+j}=\left(1+n_{t+j}\right) /\left(1+\dot{p}_{t+j}\right),
$$

where

$$
1+\dot{p}_{c, t+j}=P_{t+j} / P_{t+j-1} .
$$

Equation (3) explains the accumulation of stock of durable goods $S$ with a physical depreciation rate $\delta$. Note that we assume that the value of services from durable goods is proportional to their stock and hence do not distinguish between $S$ in the utility function in (1) and the constraint in (3).

Equation (4) is the public sector's intertemporal budget constraint showing how the stock of public debt, $B$, evolves; $G$ is public expenditure and $q_{g}$ is its relative price, i.e. 
$q_{g, t+j}=P_{g, t+j} / P_{t+j}$

Finally, equation (5) gives the decomposition of private financial wealth into private and public assets and bonds. Equations (2)-(5) can be combined to give the consolidated budget constraint which shows the evolution of private sector's net total wealth $A_{t+j}+q_{d, t+j} S_{t+j}=\left(1+r_{t+j}\right) A_{t+j-1}+\left(1-\delta_{t+j}\right) q_{d, t+j-l} S_{t+j-1}+X_{t+j}-q_{c, t+j} C_{t+j}-q_{g, t+j} G_{t+j}$.

The first order conditions for choosing the path of $C$ and $S$ which maximise the expected value of (1) subject to (11) are given below and hold for $j \geq 0$, where $E_{t}$ is the mathematical expectations operator (conditional on the information set available at $t$ ) and $\lambda$ is the Lagrange multiplier.

$$
\begin{aligned}
& E_{t}\left(\frac{\partial U_{t}}{\partial C_{t+j}}-\lambda_{t+j} q_{c, t+j}\right)=0, \\
& E_{t}\left(\frac{\partial U_{t}}{\partial S_{t+j}}-\lambda_{t+j} q_{d, t+j}+\lambda_{t+j+l}\left(1-\delta_{t+j+l}\right) q_{d, t+j+1}\right)=0,
\end{aligned}
$$

and

$$
E_{t}\left(\lambda_{t+j}-\lambda_{t+j+1}\left(1+r_{t+j+1}\right)\right)=0 \text {. }
$$

The consolidated approach mentioned above focuses on estimating the intertemporal path of consumption which can be derived as a closed form solution to equations (11)-(14) and an explicit functional form for the utility function, $u(C, S ; G)$. In this paper we concentrate on estimating the intra-temporal marginal rate of substitution between $C$ and $S$ which we obtain from (12)-(14), that is

$$
\frac{\partial u\left(C_{t}, S_{t} ; G_{t}\right) / \partial S_{t}}{\partial u\left(C_{t}, S_{t} ; G_{t}\right) / \partial C_{t}}=\left(\frac{q_{d, t}}{q_{c, t}}\right) \cdot\left(1+E_{t}\left(\frac{\left(1-\delta_{t+j+1}\right)\left(1+\dot{q}_{d, t+1}\right)}{1+r_{t+1}}\right)\right) .
$$


Equation (15) is a modified version of the conventional definition which equates the marginal rate substitution with the relative price, where the modification is due to the opportunity cost associated with durable goods and is captured by the ratio in the second brackets on the right-hand-side of (15). By replacing $u(C, S ; G)$ with a specific utility function, (15) will give us an equilibrium relationship between $C, S, G$, and the modified relative price factor. We assume

$$
u(C, S ; G)=(1 / \sigma)\left[(1 / \gamma)\left(G^{1-a} C^{a}\right)^{\gamma}+(1 / \phi)\left(G^{1-b} S^{b}\right)^{\phi}\right]^{\sigma}
$$

which is a sufficiently general approximation of the consumer's preferences where $a, b, \gamma, \phi$ and $\sigma$ are constant parameters with standard interpretations; $0<a<1, \quad 0<b<1, \gamma<1$, $\phi<1, \sigma \leq 1$, and preferences are separable in $C$ and $S$ if $\sigma=1$. Also, $\gamma$ and $\phi$ allow for the possibility of $G$ being and Edgworth complement or substitute with respect to $C$ and/or $S$ in the relevant subutilities ${ }^{3}$. Using (16) to substitute for the expression on the right-hand-side of (15), we obtain

$(b / a)\left(S_{t}^{-(1-\phi b)}\right)\left(C_{t}^{(1-\gamma a)}\right)\left(G_{t}^{\phi(1-b)-\gamma(1-a)}\right)=\left(\frac{q_{d, t}}{q_{c, t}}\right) \cdot\left(1+E_{t}\left(\frac{\left(1-\delta_{t+j+1}\right)\left(1+\dot{q}_{d, t+1}\right)}{1+r_{t+1}}\right)\right)$ which in logarithmic form may be approximated as follows $\beta_{o}+\beta_{1} \ln S_{t}+\beta_{2} \ln C_{t}+\beta_{3} \ln G_{t}+\beta_{4} \ln Z_{t}=v_{t}$ where $\beta_{o}=\ln (b / a) ; \quad \beta_{1}=-(1-\phi b) ; \quad \beta_{2}=1-\gamma a ; \quad \beta_{3}=\phi(1-b)-\gamma(1-a) ; \quad \beta_{4}=-1$, $v_{t}$ is a general disturbance term capturing all omissions and approximation and $Z_{t}=\left(\frac{q_{d, t}}{q_{c, t}}\right) \cdot\left(1+\left(\frac{\left(1-\delta_{t+j+1}\right)\left(1+\dot{q}_{d, t+1}\right)}{1+r_{t+1}}\right)\right)$.

\footnotetext{
${ }^{3}$ Two goods are Edgworth complements (substitutes) if the marginal utility of one rises (falls) as the quantity of the other is raised
} 
In our empirical investigation in the next two sections we shall first apply cointegration tests to examine whether equation (17) can be supported as a long-run equilibrium relationship, and use this information to estimate equations which describe the paths of $C$ and $S$ and the way they are affected by $G$. These equations are then simulated to give the effect of a shock to public spending on durable and non-durable consumption by private sector. We conclude this section by using the theory developed above to anticipate the effect of a rise in $G$ on $C$ and $S$.

\subsection{Effect of a rise in public spending on the composition of private consumption}

The above framework can be used to construct a diagram which explains how a change in public consumption affects durable and non-durable private consumption. In Figure $1, I_{l}$ and $B_{1}$ show an indifference curve and a budget line in $(S, C)$ space. These are drawn for given values of $\left(B, G, T, A, r, q_{g}, q_{c}, q_{d}, \delta\right)$ and are associated with the instantaneous utility function $u(C, S ; G)$ in (1) and the budget constraint in (11) which in a stationary state equilibrium is given by

$\delta q_{d} S=\left(r A+X-q_{g} G\right)-q_{c} C$.

The tangency point between the budget constraint and the indifference curve, denoted by $A_{1}$, depicts an initial equilibrium position. We are interested in finding how a rise in $G$ changes the location of this equilibrium point. Given that $d u=u_{c}^{\prime} d C+u_{s}^{\prime} d S+u_{g}^{\prime} d G$, where all partial derivatives $\left(u_{c}^{\prime}, u_{s}^{\prime}, u_{g}^{\prime}\right)$ are positive, a rise in $G$ will imply that an indifference curve passing through point $A_{l}$ will now be associated with a higher utility level relative to $I_{l}$. In addition, because the marginal utilities $\left(u_{c}^{\prime}, u_{s}^{\prime}\right)$ depend on the level of $G$, a rise in the latter will also affect the marginal rate of substitution between $C$ and $S$. As a result, the indifference curves will rotate clockwise (anti-clockwise) if an increase in $G$ leads to a rise 
(fall) in $\left(u_{c}^{\prime} / u_{s}^{\prime}\right)$. Thus, allowing $G$ to rise and letting $\partial\left(u_{c}^{\prime} / u_{s}^{\prime}\right) / \partial G<0$, the consumer's position before adjusting $C$ and $S$ may be represented at point $A_{l}$ on the flatter indifference curve, labelled $I_{21}$ in Figure 1. Since $I_{2 l}$ is now associated with a higher utility level, the consumer may be compensated by shifting to a lower indifference curve, say $I_{22}$. Note, however, that this compensation may be achieved by moving to $I_{22}$ in three different ways: either $(i)$ reduce $C$ and raise $S$; or ( $i i)$ reduce $S$ and raise $C$; or indeed (iii) reduce both $C$ and $S$. It is nevertheless easy to verify that, given the restriction imposed by the budget constraint, the consumer is likely to choose option $(i)$ as long as the relative price $\left(q_{c} / \delta q_{d}\right)$ does not change drastically. This can be seen by noting that the effect of a change in $G$ and its accompanying budgetary implications on the budget constraint in (12) is likely to be a leftward shift in the latter. In Figure 1 the new position of the budget line is shown by $B_{2}$ and the rise in $G$ shifts the equilibrium point from $A_{l}$ to $A_{2}$, hence reducing non-durable consumption and increasing the consumption of durables. We conclude by noting that the opposite result will follow if $\partial\left(u_{c}^{\prime} / u_{s}^{\prime}\right) / \partial G>0$, since in this case a rise in $G$ will raise the marginal rate of substitution between $S$ and $C$ hence the indifference curves will rotate clockwise. 
Figure 1. Effect of a Rise in $G$ on $C$ and $S$ when $\partial\left(\mathrm{u}_{\mathrm{c}}^{\prime} / \mathrm{u}_{\mathrm{s}}^{\prime}\right) / \partial \mathrm{G}<0$

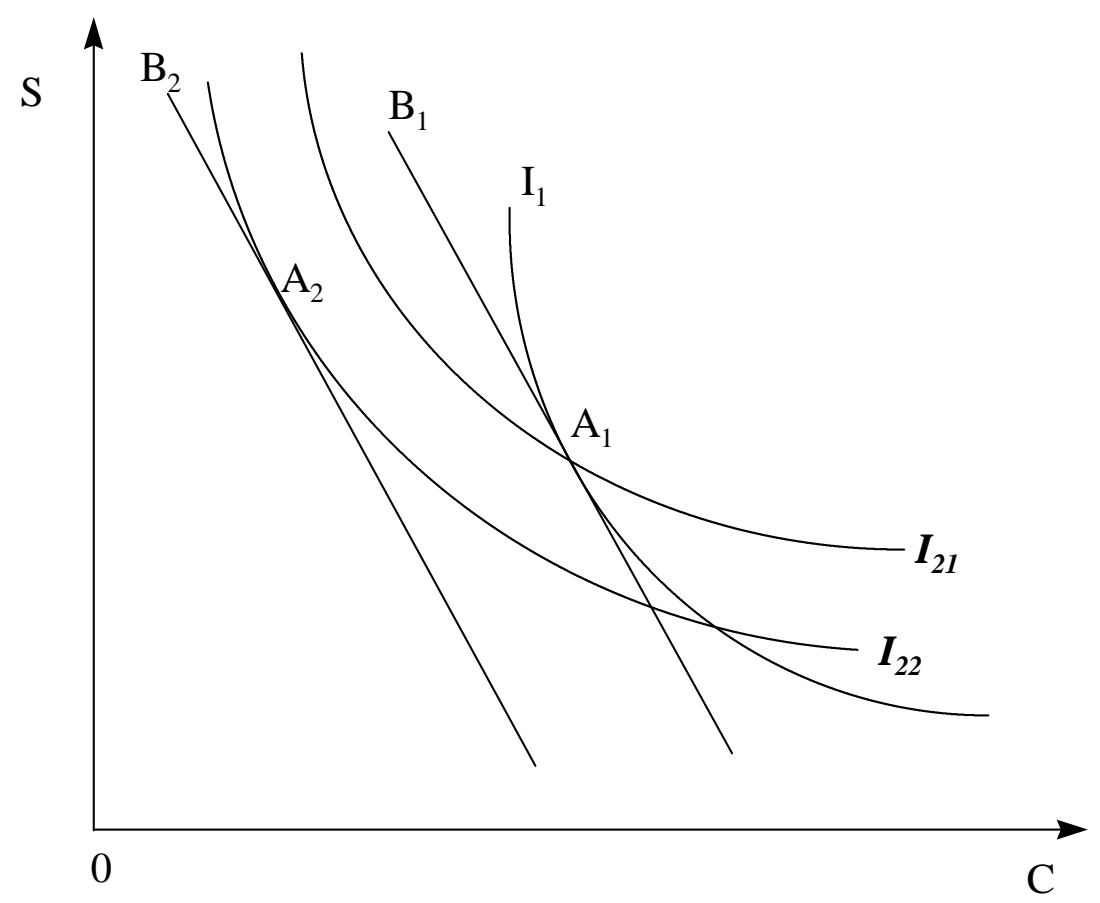

\section{Empirical evidence from the U.S. and Canada}

In this section, U.S. and Canadian time series data are used to quantify the effect of a fiscal expansion on components of private consumption as described by the theory developed above. All series are per capita, whenever relevant, with annual frequency ${ }^{4}$.

\subsection{Time series properties of the series}

Tables 1 and 2 summarise the results of units root tests which identify the degree of nonstationarity inherent in the relevant series, that is $\ln C, \ln S, \ln G$ and $\ln Z$, whose sample behaviours from 1935-1995 are depicted in Figure 2 below.

\footnotetext{
${ }^{4}$ See the Data Appendix for sources and definitions.
} 
Figure 2. U.S. and Canadian Series (1935-1995)

U.S. Per-capita Private Consumption

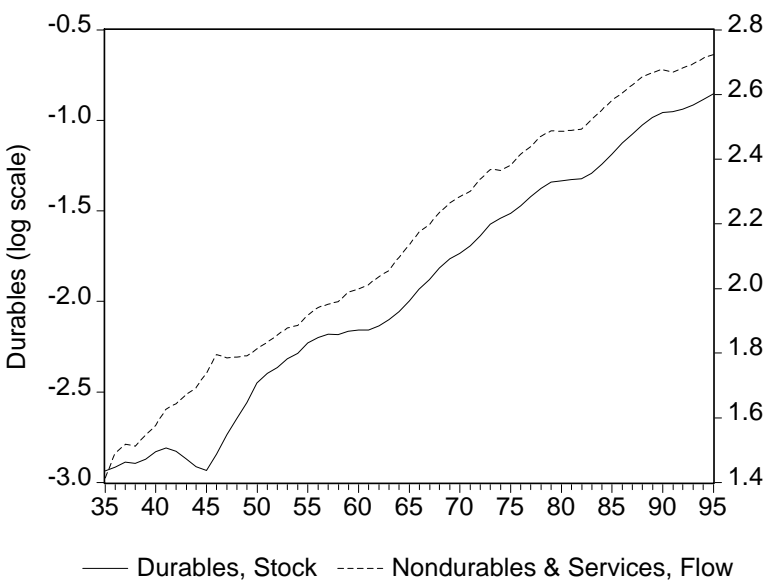

U.S. Per-capita Government Spending \& Weighted Relative Price of Durables to Nondurables \& Services

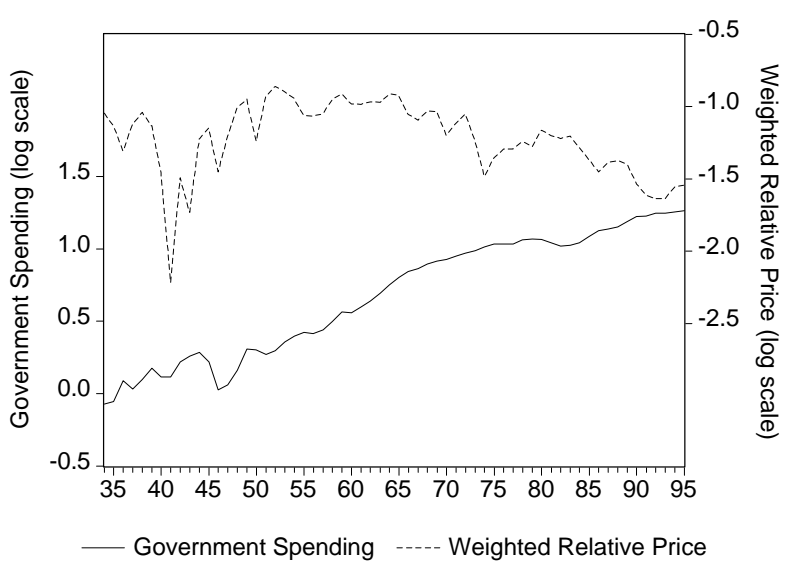

Canadian Per-capita Private Consumption

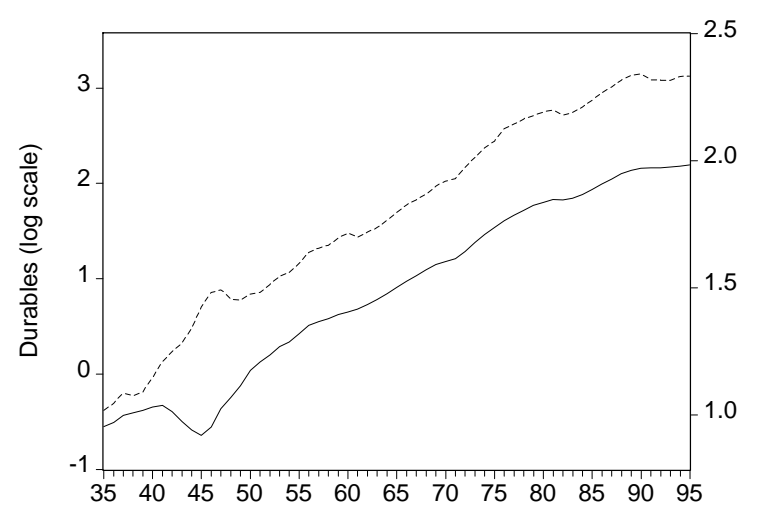

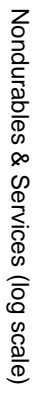

Canadian Per-capita Government Spending \& Weighted Relative Price of Durables to Nondurables \& Services

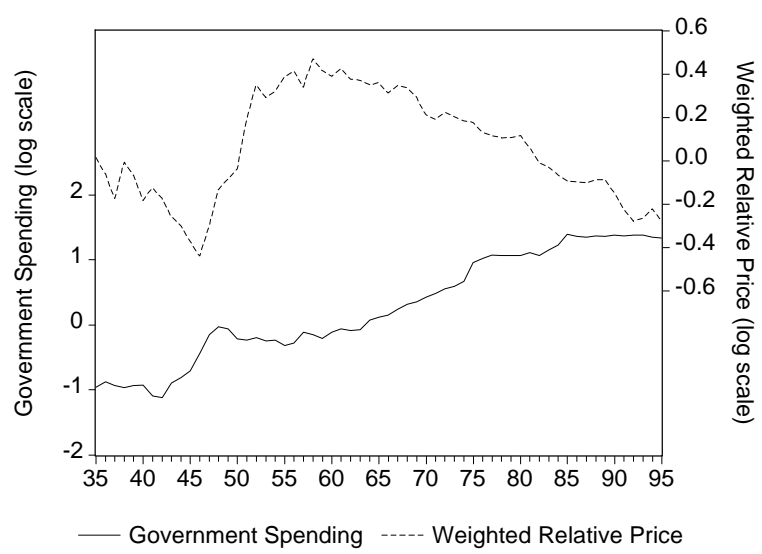

Table 1. Unit Root Tests for the U.S. Series

\begin{tabular}{|c|c|c|c|c|c|c|c|c|}
\hline & \multicolumn{4}{|c|}{ Levels } & \multicolumn{3}{c|}{ First Differences } \\
\hline & \multicolumn{2}{|c|}{$\begin{array}{c}\text { based on a regression } \\
\text { including a constant }\end{array}$} & \multicolumn{2}{c|}{$\begin{array}{c}\text { based on a regression } \\
\text { including a constant } \\
\text { and a time trend }\end{array}$} & $\begin{array}{c}\text { cased on a regression } \\
\text { including a constant }\end{array}$ & \multicolumn{2}{c|}{$\begin{array}{c}\text { based on a regression } \\
\text { including a constant } \\
\text { and a time trend }\end{array}$} \\
\hline & $\tau$ & $\boldsymbol{z}$ & $\boldsymbol{\tau}$ & $\boldsymbol{z}$ & $\tau$ & $\boldsymbol{z}$ & $\tau$ & $\boldsymbol{z}$ \\
\hline $\boldsymbol{l n} \boldsymbol{S}$ & 0.409 & -0.088 & -0.727 & -3.934 & -3.985 & -3.983 & -4.062 & -3.963 \\
& $(0.997)$ & $(0.951)$ & $(0.988)$ & $(0.011)$ & $(0.000)$ & $(0.001)$ & $(0.004)$ & $(0.053)$ \\
\hline $\boldsymbol{l n} \boldsymbol{C}$ & 1.356 & -1.499 & -0.869 & -1.351 & -5.228 & -6.269 & -5.769 & -6.411 \\
& $(0.999)$ & $(0.534)$ & $(0.982)$ & $(0.875)$ & $(0.000)$ & $(0.000)$ & $(0.000)$ & $(0.000)$ \\
\hline $\ln \boldsymbol{G}$ & 1.127 & -1.216 & -1.909 & -1.683 & -6.838 & -7.002 & -6.898 & -6.935 \\
& $(0.999)$ & $(0.667)$ & $(0.708)$ & $(0.758)$ & $(0.000)$ & $(0.000)$ & $(0.000)$ & $(0.000)$ \\
\hline $\ln \boldsymbol{Z}$ & -2.367 & -2.121 & -3.179 & -3.650 & -7.037 & -6.983 & -7.036 & -6.931 \\
& $(0.0726)$ & $(0.236)$ & $(0.515)$ & $(0.026)$ & $(0.000)$ & $(0.000)$ & $(0.000)$ & $(0.000)$ \\
\hline
\end{tabular}

1- $z$ is the Dickey-Fuller $(1979,1981)$ test statistic for the existence of a unit root. $\tau$ is the Weighted Symmetric test statistic proposed by Pantula et al (1994). They show that $\tau$ dominates $\mathbf{z}$ in terms of power.

2- The AIC (see Akaike, 1973) was used to choose the optimal lag length which was found to be two years.

Pantula $e t$ al. argue that the AIC avoids size distortions for both the $\tau$ and $z$.

3- Numbers in parentheses are the p-values(see, MacKinnon, 1994).

4- All above tests results were also supported by the test statistics proposed by Phillips and Perron (1988). 
Table 2. Unit Root Tests for the Canadian Series

\begin{tabular}{|c|c|c|c|c|c|c|c|c|}
\hline & \multicolumn{4}{|c|}{ Levels } & \multicolumn{4}{|c|}{ First Differences } \\
\hline & \multicolumn{2}{|c|}{$\begin{array}{l}\text { based on a regression } \\
\text { including a constant }\end{array}$} & \multicolumn{2}{|c|}{$\begin{array}{l}\text { based on a regression } \\
\text { including a constant } \\
\text { and a time trend }\end{array}$} & \multicolumn{2}{|c|}{$\begin{array}{l}\text { based on a regression } \\
\text { including a constant }\end{array}$} & \multicolumn{2}{|c|}{$\begin{array}{c}\text { based on a regression } \\
\text { including a constant } \\
\text { and a time trend } \\
\end{array}$} \\
\hline & $\tau$ & $z$ & $\tau$ & $z$ & $\tau$ & $z$ & $\tau$ & $z$ \\
\hline $\ln S$ & $\begin{array}{c}0.303 \\
(0.996)\end{array}$ & $\begin{array}{l}-0.793 \\
(0.821)\end{array}$ & $\begin{array}{l}-0.389 \\
(0.995)\end{array}$ & $\begin{array}{l}-2.381 \\
(0.390)\end{array}$ & $\begin{array}{l}-3.906 \\
(0.000)\end{array}$ & $\begin{array}{l}-3.723 \\
(0.003)\end{array}$ & $\begin{array}{l}-3.918 \\
(0.006)\end{array}$ & $\begin{array}{l}-3.694 \\
(0.006)\end{array}$ \\
\hline $\ln C$ & $\begin{array}{l}-0.276 \\
(0.976)\end{array}$ & $\begin{array}{l}-1.133 \\
(0.701)\end{array}$ & $\begin{array}{l}-2.789 \\
(0.149)\end{array}$ & $\begin{array}{l}-2.759 \\
(0.212)\end{array}$ & $\begin{array}{l}-5.221 \\
(0.000)\end{array}$ & $\begin{array}{l}-5.104 \\
(0.000)\end{array}$ & $\begin{array}{l}-5.238 \\
(0.000)\end{array}$ & $\begin{array}{l}-5.058 \\
(0.000)\end{array}$ \\
\hline $\ln G$ & $\begin{array}{c}-0347 \\
(0.988)\end{array}$ & $\begin{array}{l}-1.191 \\
(0.746)\end{array}$ & $\begin{array}{l}-2.098 \\
(0.579)\end{array}$ & $\begin{array}{l}-2.222 \\
(0.478)\end{array}$ & $\begin{array}{l}-5.349 \\
(0.000)\end{array}$ & $\begin{array}{l}-5.184 \\
(0.000)\end{array}$ & $\begin{array}{l}-5.370 \\
(0.000)\end{array}$ & $\begin{array}{l}-5.160 \\
(0.000)\end{array}$ \\
\hline $\ln Z$ & $\begin{array}{l}-1.205 \\
(0.716)\end{array}$ & $\begin{array}{c}0.778 \\
(0.825)\end{array}$ & $\begin{array}{l}-1.231 \\
(0.948)\end{array}$ & $\begin{array}{l}-0.756 \\
(0.969)\end{array}$ & $\begin{array}{l}-5.209 \\
(0.000)\end{array}$ & $\begin{array}{l}-5.402 \\
(0.000)\end{array}$ & $\begin{array}{l}-5.414 \\
(0.000)\end{array}$ & $\begin{array}{l}-5.806 \\
(0.000)\end{array}$ \\
\hline
\end{tabular}

See notes to Table 1 .

Based on the evidence reported in Tables 1 and 2, it is quite clear that $\ln S_{t}, \ln C_{t}$ and $\ln G_{t}$ contain a unit root and $\Delta \ln S_{t}, \Delta \ln C_{t}$ and $\Delta \ln G_{t}$ are stationary, where $\Delta$ is the first difference operator. However, while for Canada $\ln Z_{t}$ contains a unit root and $\Delta \ln Z_{t}$ is stationary, we cannot reject the hypothesis that for the U.S. $\ln Z_{t}$ is stationary around a linear deterministic trend ${ }^{5}$. Using these results, we proceed to examine the cointegration properties of the vector $\left(\ln S_{t}, \ln C_{t}, \ln G_{t}, \ln Z_{t}\right)$. We base our tests on a generalised version of Johansen's Trace and Maximal Eigenvalue test statistics calculated by estimating a VAR system in which $\left(\ln S_{t}, \ln C_{t}\right)$ are endogenous and $\left(\ln G_{t}, \ln Z_{t}\right)$ are exogenous ${ }^{6}$. As a result, for each country we may expect to find a maximum of two cointegrating relationships. The results of the tests for the U.S. and Canada are given in Tables 3 and 4 below.

\footnotetext{
${ }^{5}$ Regressions for $\ln Z$ in the latter case included an intercept dummy for the period 1941-1947. This improved the efficiency of estimates but did not alter the conclusion that the series were stationary around a linear deterministic time trend.

${ }^{6}$ Note that this classification is consistent with the theory developed in Section 2 and is also supported empirically. For further details see the notes under Tables 3 and 4.
} 
Table 3. Cointegration Tests for the U.S.

\begin{tabular}{|c|c|c|c|c|c|c|c|c|c|}
\hline \multicolumn{5}{|c|}{ Maximal Eigenvalue Test } & \multicolumn{5}{|c|}{ Trace Test } \\
\hline $\boldsymbol{H}_{\boldsymbol{o}}$ & $\mathrm{H}_{1}$ & $\begin{array}{c}\text { Statistic } \\
\text { Value }\end{array}$ & $\begin{array}{l}95 \% \\
\text { C.V. }\end{array}$ & $\begin{array}{l}90 \% \\
\text { C.V. }\end{array}$ & $\boldsymbol{H}_{o}$ & $\mathrm{H}_{1}$ & $\begin{array}{c}\text { Statistic } \\
\text { Value }\end{array}$ & $\begin{array}{l}95 \% \\
\text { C.V. }\end{array}$ & $\begin{array}{l}90 \% \\
\text { C.V. }\end{array}$ \\
\hline$\rho=0$ & $\rho=1$ & 25.83 & 18.06 & 15.98 & $\rho=0$ & $\rho=1$ & 30.83 & 23.32 & 20.75 \\
\hline$\rho \leq 0$ & $\rho=2$ & 4.439 & 11.47 & 9.53 & $\rho=0$ & $\rho=2$ & 4.44 & 11.47 & 9.53 \\
\hline
\end{tabular}

Tests are based on an unrestricted VAR(2) system with unrestricted intercepts and no deterministic trend. The AIC was used to choose the optimal lag length and the omission of a time trend was supported statistically. The VAR system consisted of two equations for $\ln S_{t}$ and $\ln C_{t}$ which included $\ln G_{t}$ as an exogenous $\mathbf{I}(\mathbf{1})$ variable and detrended $\ln Z_{t}$ as an exogenous $\mathbf{I}(\boldsymbol{0})$ variable. Critical values in both Tables 3 and 4 are from Pesaran, et al. (1996).

Table 4. Cointegration Tests for Canada

\begin{tabular}{|c|c|c|c|c|c|c|c|c|c|}
\hline \multicolumn{5}{|c|}{ Maximal Eigenvalue Test } & \multicolumn{5}{|c|}{ Trace Test } \\
\hline $\boldsymbol{H}_{\boldsymbol{o}}$ & $\mathrm{H}_{1}$ & $\begin{array}{c}\text { Statistic } \\
\text { Value }\end{array}$ & $\begin{array}{l}95 \% \\
\text { C.V. }\end{array}$ & $\begin{array}{l}90 \% \\
\text { C.V. }\end{array}$ & $\mathrm{H}_{o}$ & $\mathrm{H}_{1}$ & $\begin{array}{c}\text { Statistic } \\
\text { Value }\end{array}$ & $\begin{array}{l}95 \% \\
\text { C.V. }\end{array}$ & $\begin{array}{l}90 \% \\
\text { C.V. }\end{array}$ \\
\hline$\rho=0$ & $\rho=1$ & 21.52 & 18.06 & 15.98 & $\rho=0$ & $\rho=1$ & 26.22 & 23.32 & 20.75 \\
\hline$\rho \leq 0$ & $\rho=2$ & 4.70 & 11.47 & 9.53 & $\rho=0$ & $\rho=2$ & 4.70 & 11.47 & 9.53 \\
\hline
\end{tabular}

Tests are based on an unrestricted VAR(2) system with unrestricted intercepts and no deterministic trend. The AIC was used to choose the optimal lag length and the omission of a time trend was supported statistically. The VAR system consisted of two equations for $\ln S_{t}$ and $\ln C_{t}$ which included $\ln G_{t}$ as an exogenous $I(1)$ variable and $\Delta \ln Z_{t}$ as an exogenous $I(0)$ variable. Note that this specification was found to be statistically superior to the one which included $\ln Z_{t}$ as an exogenous $I(1)$ variable. For example, a test of the overidentifying restriction that $\ln Z_{t}$ should be excluded from the cointegrating vector could not be rejected. The LM test in this case was $\chi 2(1)=0.88$.

Given the results of cointegration tests reported in Tables 3 and 4, it is clear that both the U.S. and Canadian series support the existence of a unique cointegrating vector. This hypothesis was further supported by the commonly used Information Criteria which are reported in Table 5 below. Finally Table 6 gives the maximum likelihood estimates of the normalised cointegrating vectors for the U.S. and Canada.

Table 5. Information Criteria for VAR(2) Specification with Rank Restrictions

\begin{tabular}{|c|c|c|c|c|c|c|c|c|c|}
\hline \multicolumn{9}{|c|}{ U.S. } & \multicolumn{6}{c|}{ CANADA } \\
\hline Rank & $\boldsymbol{L}$ & $\boldsymbol{A I C}$ & $\boldsymbol{S B C}$ & $\boldsymbol{H Q C}$ & Rank & $\boldsymbol{L}$ & $\boldsymbol{A I C}$ & $\boldsymbol{S B C}$ & $\boldsymbol{H Q C}$ \\
\hline $\boldsymbol{\rho}=\mathbf{0}$ & 332.3 & 322.3 & 311.8 & 318.2 & $\boldsymbol{\rho}=\mathbf{0}$ & 288.8 & 276.8 & 264.2 & 271.9 \\
\hline $\boldsymbol{\rho}=\mathbf{1}$ & 345.2 & 331.2 & 316.5 & 325.5 & $\boldsymbol{\rho}=\mathbf{1}$ & 299.6 & 283.6 & 266.8 & 277.0 \\
\hline $\boldsymbol{\rho}=\mathbf{2}$ & 347.4 & 331.4 & 314.7 & 324.9 & $\boldsymbol{\rho}=\mathbf{2}$ & 301.9 & 283.9 & 265.0 & 276.6 \\
\hline
\end{tabular}

$\rho$ is the rank of the $\Pi$ matrix in Johansen's Transformation of the VAR system. L: maximum loglikelihood; AIC: Akaike (1973) Information Criterion; SBC: Schwarz (1978) Information Criterion; and HQC: Hannan-Quinn (1979) Criterion. 
Table 6. Estimates of the Normalised Cointegration Vectors

\begin{tabular}{|c|c|c|c|c|c|}
\hline \multicolumn{3}{|c|}{ U.S. } & \multicolumn{3}{c|}{ Canada } \\
\hline Variable & Coefficient & S.E & Variable & Coefficient & S.E \\
\hline $\ln \boldsymbol{S}_{t}$ & 1 & -- & $\ln S_{\mathrm{t}}$ & 1 & -- \\
\hline $\ln \boldsymbol{C}_{t}$ & -3.055 & 0.565 & $\ln C_{\mathrm{t}}$ & -1.482 & 0.382 \\
\hline $\ln \boldsymbol{G}_{t}$ & 1.144 & 0.496 & $\operatorname{lnG}_{\mathrm{t}}$ & -0.384 & 0.189 \\
\hline
\end{tabular}

$\boldsymbol{S . E}$ is the asymptotic standard error calculated from the estimated variance covariance matrix. Note that as explained above $\ln Z_{t}$ does not appear in the cointegration relationship.

\subsection{Estimating the paths of $S$ and $C$}

The above results suggest that the unrestricted VAR(2) specifications for $\ln S$ and $\ln C$ can be restricted according to an error-correction specification. We therefore approximate the paths of $C$ and $S$ by the following regression equations ${ }^{7}$

$$
\Delta \ln S_{t}=b_{s o}+b_{s 1} \Delta \ln S_{t-1}+b_{s 2} \Delta \ln C_{t-1}+b_{s 3} \Delta \ln G_{t-1}+b_{s 4} \Delta \ln Z_{t-1}+b_{s 5} E C M_{t-1}+\varepsilon_{s t}
$$

and

$$
\Delta \ln C_{t}=b_{c o}+b_{c 1} \Delta \ln S_{t-1}+b_{c 2} \Delta \ln C_{t-1}+b_{c 3} \Delta \ln G_{t-1}+b_{c 4} \Delta \ln Z_{t-1}+b_{c 5} E C M_{t-1}+\varepsilon_{c, t}
$$

where $E C M$ is the error-correction term which is approximated by the residuals from the respective cointegration relationships reported in Table 6. Estimates of equations (20) and (21) for the U.S. and Canada are reported in Tables 7 and 8, respectively. In each case, column (I) gives estimates of the general specification and column (II) provides estimates of the restricted or parsimonious version which omits the insignificant regressors. The relevant test statistics are also reported in these Tables which show that the estimates in column (II) are empirically robust and can be used to examine the impact of a change in $G$ on $C$ and $S$ by means of simulation analysis.

\footnotetext{
${ }^{7}$ See Molana (1991) for a similar application of the error correction modelling based on an equilibrium relationship between consumption and wealth.
} 
Table 7. Estimates of Equations (20) and (21) for the U.S. Annual Series for Period 1936-1995

\begin{tabular}{|c|c|c|c|c|c|}
\hline \multicolumn{3}{|c|}{$\begin{array}{c}\text { Durarable Consumption } \\
\text { Dependent Variable } \Delta \ln S_{t}\end{array}$} & \multicolumn{3}{|c|}{$\begin{array}{c}\text { Non-Durarable Consumption } \\
\text { Dependent Variable } \Delta \ln C_{t}\end{array}$} \\
\hline Regressor & (I) & (II) & Regressor & (I) & (II) \\
\hline$\Delta \ln S_{t-1}$ & $\begin{array}{l}0.564 \\
(6.58)\end{array}$ & $\begin{array}{l}0.594 \\
(7.06)\end{array}$ & $\Delta \ln S_{t-1}$ & $\begin{array}{l}-0126 \\
(1.99)\end{array}$ & -- \\
\hline$\Delta \ln C_{t-1}$ & $\begin{array}{l}0.211 \\
(1.31) \\
\end{array}$ & - & $\Delta \ln C_{t-1}$ & $\begin{array}{l}0.026 \\
(2.20) \\
\end{array}$ & -- \\
\hline$\Delta \ln G_{t-1}$ & $\begin{array}{l}0.072 \\
(1.22)\end{array}$ & - & $\Delta \ln G_{t-1}$ & $\begin{array}{l}0.021 \\
(0.48) \\
\end{array}$ & - \\
\hline$\Delta \ln Z_{t-1}$ & $\begin{array}{l}-0.058 \\
(4.03)\end{array}$ & $\begin{array}{l}-0.058 \\
(4.00)\end{array}$ & $\Delta \ln Z_{t-1}$ & $\begin{array}{l}-0.016 \\
(1.50) \\
\end{array}$ & $\overline{--}$ \\
\hline $\operatorname{ECM}_{t-1}$ & $\begin{array}{l}-0.055 \\
(2.84)\end{array}$ & $\begin{array}{l}-0.041 \\
(2.44)\end{array}$ & $E C M_{t-1}$ & $\begin{array}{l}0.026 \\
(1.77) \\
\end{array}$ & $\begin{array}{l}0.048 \\
(4.76)\end{array}$ \\
\hline Constant & $\begin{array}{l}-0.416 \\
(2.77)\end{array}$ & $\begin{array}{l}-0.302 \\
(2.35)\end{array}$ & Constant & $\begin{array}{l}0.216 \\
(1.94)\end{array}$ & $\begin{array}{l}0.392 \\
(5.03)\end{array}$ \\
\hline \multicolumn{3}{|c|}{ Diagnostic Statistics } & \multicolumn{3}{|c|}{ Diagnostic Statistics } \\
\hline$R^{2}$ & 0.654 & 0.638 & $R^{2}$ & 0.279 & 0.361 \\
\hline S.E & 0.0189 & 0.0190 & S.E & 0.01404 & 0.1279 \\
\hline$L$ & 156.004 & 154.59 & $L$ & 173.98 & 183.823 \\
\hline$A I C$ & 150.004 & 150.592 & $A I C$ & 167.98 & 180.823 \\
\hline$S B C$ & 143.72 & 146.40 & $S B C$ & 161.70 & 177.632 \\
\hline$D W$ & 1.857 & 1.837 & $D W$ & 1.785 & 1.679 \\
\hline$T_{1}$ & 0.644 & 0.575 & $T_{1}$ & 1.577 & 1.595 \\
\hline$T_{2}$ & 0.0115 & 0.0081 & $T_{2}$ & 1.1456 & 0.0015 \\
\hline$T_{3}$ & 5.245 & 2.526 & $T_{3}$ & 0.0835 & 1.815 \\
\hline$T_{4}$ & 0.667 & 0.803 & $T_{4}$ & 6.339 & 2.253 \\
\hline$T_{5}$ & $\begin{array}{c}20.47 \\
(5,54)\end{array}$ & $\begin{array}{c}32.90 \\
(3,56) \\
\end{array}$ & $T_{5}$ & $\begin{array}{l}4.175 \\
(5,54)\end{array}$ & $\begin{array}{c}16.66 \\
(2,59)\end{array}$ \\
\hline$T_{6}$ & $\begin{array}{c}1.301 \\
(2,54) \\
\end{array}$ & $\begin{array}{ll}- \\
-\end{array}$ & $T_{6}$ & $\begin{array}{c}2.434 \\
(4,54) \\
\end{array}$ & -- \\
\hline $\boldsymbol{T}_{7}$ & -- & $\begin{array}{c}2.527 \\
(2,53)\end{array}$ & $\boldsymbol{T}_{7}$ & & $\begin{array}{c}0.258 \\
(2,55)\end{array}$ \\
\hline
\end{tabular}

- The final regression for $\Delta \ln C$ included an intercept dummy for 1946.

- $\Delta \ln Z$ is constructed using the detrended values of $\ln Z$.

- Numbers in parentheses are the t-ratios.

- $L$ is the $\log$-likelihood value.

- AIC and SBC are Akaike and Schwarz Information Criteria respectively.

- $T_{1}$ : Lagrange Multiplier test for $1^{\text {st }}$ order autocorrelation, distributed asymptotically as $\chi^{2}(1)$.

- $T_{2}$ : RESET test distributed, asymptotically as $\chi^{2}(1)$.

- $T_{3}$ : Normality test, distributed asymptotically as $\chi^{2}(2)$.

- $T_{4}$ : Heteroscedasticity test, distributed asymptotically as $\chi^{2}(1)$.

- $T_{5}: F$ Test for joint significance of the coefficients, $d . f$. in parentheses.

- $T_{6}: F$ Test for joint significance of the omitted regressors, $d . f$. in parentheses.

- $T_{7}: F$ Test for joint significance of the added regressors, $d . f$. in parentheses. 
Table 8. Estimates of Equations (20) and (21) for Canada Annual Series for Period 1936-1995

\begin{tabular}{|c|c|c|c|c|c|}
\hline \multicolumn{3}{|c|}{$\begin{array}{c}\text { Durarable Consumption } \\
\text { Dependent Variable } \Delta \ln S_{t}\end{array}$} & \multicolumn{3}{|c|}{$\begin{array}{c}\text { Non-Durarable Consumption } \\
\text { Dependent Variable } \Delta \ln C_{t} \\
\end{array}$} \\
\hline Regressor & (I) & (II) & Regressor & (I) & (II) \\
\hline$\Delta \ln S_{t-1}$ & $\begin{array}{l}0.549 \\
(4.24)\end{array}$ & $\begin{array}{l}0.555 \\
(5.45)\end{array}$ & $\Delta \ln S_{t-1}$ & $\begin{array}{l}-0269 \\
(0.34)\end{array}$ & -- \\
\hline$\Delta \ln C_{t-1}$ & $\begin{array}{l}0.291 \\
(1.22)\end{array}$ & -- & $\Delta \ln C_{t-1}$ & $\begin{array}{l}0.321 \\
(2.20)\end{array}$ & $\begin{array}{l}0.298 \\
(2.22)\end{array}$ \\
\hline$\Delta \ln G_{t-1}$ & $\begin{array}{l}0.042 \\
(0.87) \\
\end{array}$ & - & $\Delta \ln G_{t-1}$ & $\begin{array}{l}0.010 \\
(0.34) \\
\end{array}$ & -- \\
\hline$\Delta \ln Z_{t-1}$ & $\begin{array}{l}-0.032 \\
(0.46)\end{array}$ & -- & $\Delta \ln Z_{t-1}$ & $\begin{array}{l}-0.05 \\
(1.30) \\
\end{array}$ & -- \\
\hline $\operatorname{ECM}_{t-1}$ & $\begin{array}{l}-0.104 \\
(3.78)\end{array}$ & $\begin{array}{l}-0.105 \\
(4.59)\end{array}$ & $E C M_{t-1}$ & $\begin{array}{l}0.016 \\
(0.97)\end{array}$ & $\begin{array}{l}0.026 \\
(2.09)\end{array}$ \\
\hline Constant & $\begin{array}{l}-0.179 \\
(3.62)\end{array}$ & $\begin{array}{l}-0.174 \\
(4.31)\end{array}$ & Constant & $\begin{array}{l}0.044 \\
(1.44)\end{array}$ & $\begin{array}{l}0.061 \\
(2.59)\end{array}$ \\
\hline \multicolumn{3}{|c|}{ Diagnostic Statistics } & \multicolumn{3}{|c|}{ Diagnostic Statistics } \\
\hline$R^{2}$ & 0.6981 & 0.680 & $R^{2}$ & 0.3897 & 0.3480 \\
\hline S.E & 0.0286 & 0.0286 & S.E & 0.01747 & 0.1757 \\
\hline$L$ & 131.85 & 130.11 & $L$ & 161.43 & 159.44 \\
\hline$A I C$ & 124.850 & 126.115 & $A I C$ & 154.426 & 155.440 \\
\hline$S B C$ & 117.520 & 121.926 & $S B C$ & 147.096 & 151.252 \\
\hline$D W$ & 1.939 & 1.743 & $D W$ & 1.582 & 1.743 \\
\hline$T_{1}$ & 0.0813 & 1.683 & $T_{1}$ & 13.41 & 4.154 \\
\hline$T_{2}$ & 25.09 & 23.60 & $T_{2}$ & 0.889 & 0.496 \\
\hline$T_{3}$ & 5.193 & 4.57 & $T_{3}$ & 1.648 & 1.559 \\
\hline$T_{4}$ & 26.425 & 20.36 & $T_{4}$ & 0.0335 & 0.139 \\
\hline$T_{5}$ & $\begin{array}{c}20.42 \\
(6,53)\end{array}$ & $\begin{array}{c}39.69 \\
(3,56)\end{array}$ & $T_{5}$ & $\begin{array}{l}5.641 \\
(6,53)\end{array}$ & $\begin{array}{c}9.962 \\
(3,56)\end{array}$ \\
\hline$T_{6}$ & $\begin{array}{c}1.052 \\
(3,53)\end{array}$ & -- & $T_{6}$ & $\begin{array}{c}1.209 \\
(3,53)\end{array}$ & -- \\
\hline $\boldsymbol{T}_{7}$ & -- & $\begin{array}{c}0.839 \\
(2,53)\end{array}$ & $\boldsymbol{T}_{7}$ & & $\begin{array}{c}1.969 \\
(2,53)\end{array}$ \\
\hline
\end{tabular}

- All regressions included an intercept dummy for the Word War II period.

- See notes in Table 7 for other details.

Before discussing the results of our simulation exercise, it is worth noting that the estimates in column (II) in Tables 7 and 8 are simple generalisations of the Rational Expectations model of the consumption proposed by Hall (1978), whose implications may be summarised as follows:

(a) In both countries, the past deviations from the equilibrium level of marginal rate of substitution, captured by the ECM term, affects the path of both $C$ and $S$.

(b) In both countries, the effect of fiscal policy on the path of $C$ and $S$ seems to be restricted to the way $G$ appears in the $E C M$ term only. This is because ( $i$ ) additional terms in past $G$ were insignificant when added as regressors, and (ii) changes in the real disposable 
income and the interest rate were insignificant when added to the final equation (the test statistic for this hypothesis is $\boldsymbol{T}_{7}$ in Tables 7 and 8).

(c) In both countries, $\Delta \ln S$ exhibit a significant degree of persistence which is captured by an autoregressive pattern.

(d) Changes in the relative price only affect the path of $S$ in the U.S. and have no effect on the path of $C$ in either country.

(e) In Canada, $\Delta \ln C$ exhibits a significant degree of persistence which is captured by an autoregressive pattern, but as expected, the autoregressive coefficient of $\Delta \ln C$ is considerably lower than the one corresponding to $\Delta \ln S$.

(f) In the U.S., $\Delta \ln C$ does not show any persistence above that captured implicitly by the ECM term.

\subsection{Effect of an exogenous shock to $G$ on components of private consumption}

We now examine how a change in $G$ affects components of private expenditure on goods and services, that is $C$ and $D$. To do so, we first need to quantify the path of $Z$ and $G$ as exogenous variables. We assumed that $\Delta Z=0$ since the univariate results indicated that it is stationary and modelled $\ln G$ as an ARIMA process (see Table 9 below).

Table 9. Estimates of the Path of G Annual Series for Period 1936-1995 Dependent Variable $\Delta \ln G_{t}$

\begin{tabular}{|c|c|c|}
\hline & U.S. & CANADA \\
\hline Regressors & & \\
\hline Intercept & 0.022 & 0.024 \\
& $(3.29)$ & $(1.98)$ \\
\hline$\Delta \boldsymbol{l n} \boldsymbol{G}_{\boldsymbol{t}-\boldsymbol{I}}$ & 0.1863 & 0.3428 \\
& $(1.55)$ & $(2.75)$ \\
\hline$\Delta \boldsymbol{\operatorname { l n } \boldsymbol { G } _ { \boldsymbol { t } - 2 }}$ & -0.289 & -- \\
& $(2.41)$ & \\
\hline $\boldsymbol{R}^{2}$ & 0.1155 & 0.1174 \\
\hline $\boldsymbol{S . \boldsymbol { E }}$ & 0.0443 & 0.0857 \\
\hline $\boldsymbol{T}_{\boldsymbol{l}}$ & 0.873 & 2.943 \\
\hline $\boldsymbol{T}_{\boldsymbol{2}}$ & 0.0326 & 0.4923 \\
\hline
\end{tabular}

$T_{1}$ and $T_{2}$ are Lagrange Multiplier test statistics for $1^{\text {st }}$ order autocorrelation and heteroscedasticity, distributed asymptotically as $\chi^{2}(1)$. 
The simulation model for each country was defined by a system of five equations consisting of: (a) paths of $C$ and $S$ given in column (II) of Table 7 or 8 ; (b) path of $G$ in the relevant column of Table 9; (c) definition of the error-correction term given by the following $E C M_{t}=\ln S_{t}-\theta_{1} \ln C_{t}-\theta_{1} \ln G_{t}$ whose coefficient estimates are reported in the relevant columns of Table 6; and $(d)$ the stock-flow relationship in (3) explaining the physical accumulation process for $S$.

Our simulations consist of obtaining the forward solutions of these equations for 50 years starting from 1996. First we calculated the base simulations without any shocks to $G$ and then we repeated the experiment with both a temporary and a permanent shock. The former consisted of a once-and-for-all change in the level of $G$ in 1996, such that the value of $G$ returns to its path given by the estimated equation. The permanent shock in contrast maintained this shock by allowing the rise in the 1996 value to feed into the future levels of $G$. The effects of the temporary and permanent shocks were then calculated by the deviation of the respective series from their corresponding base simulation. Figure 3 below illustrates the results for the U.S. and Canada respectively which are summarised below:

(a) These results confirm our theoretical prediction in the previous section that a shock to $G$ has opposite effects on the main components of private consumption. As these Figures show, both the immediate and the total effects of a change in $G$ on $C$ and $D$ (and hence $S$ ) go in different directions in both countries.

(b) These results also support our conjecture that consumers' preferences have a clear role in determining which component of consumers' expenditure is crowded out. A rise in $G$ erodes nondurable consumption and raises the accumulation of durable goods in Canada, whereas the opposite result emerges for the U.S..

(c) In general, a once-and-for-all shock seems to have more effect on durables. As a result, the sector producing durable goods is likely to experience longer and more announced cycles following a fiscal shock.

(d) While nondurables response to a permanent shock to $G$ is monotonic, durables seem to respond to this shock by overshooting their long-run value. 
Figure 3. U.S. and Canadian Simulations
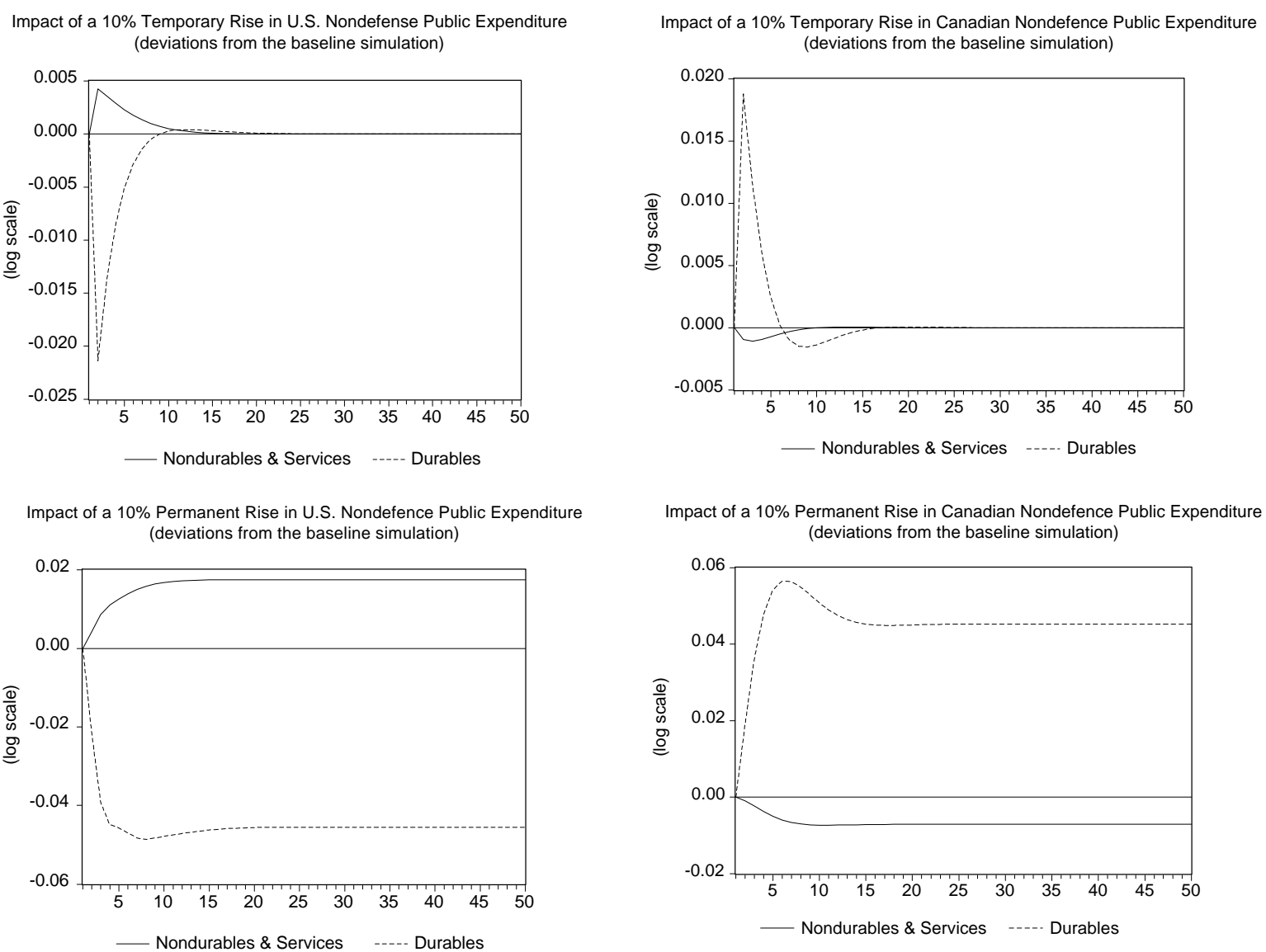

It is worth concluding this section by stressing the robustness of the above results.

The fact that these results are obtained within a partial equilibrium framework which does not take account of the way governments finance a rise in $G$ may be seen as a weakness which undermines their robustness. It may therefore be argued that our simulation results do not give the full picture since they do not allow for the paths of $C$ and $S$ to be affected by the budgetary implications of the rise in $G$. Or, put differently, our results do not capture the second round effects of a fiscal expansion on consumption that are due to the effect of disposable income and/or interest rate which are affected by the expansion and its financing. However this criticism does not apply here since the empirical results reported in Tables 7 and 8 above have ruled out the existence of a significant second round effect; our tests 
showed clearly that the information contained in changes in disposable income and the interest rate did not significantly contribute to explaining the paths of $C$ and $S$.

\section{Summary and Conclusion}

In this paper we have focused on measuring the relative effects of a fiscal shock on components of consumers' expenditure on goods and services. The theory underlying our exercise was developed in Section 1 on the basis of a generalised version of the life-cycle model (with a representative consumer and infinite horizon) in which consumers' preferences are defined over components of consumption and are affected by the level of public expenditure on goods and services. We used this model to illustrate that a rise in public spending is likely to have opposite effects on the major components of consumption (durable and nondurable consumption), hence showing that the crowding out of private consumption could in fact be a demand side phenomenon caused by the way preferences respond to a change in public spending. We also used the first order conditions for utility maximisation to derive an intra-temporal equilibrium condition which relates the marginal rate of substitution between durable and nondurable consumption to their price ratio. This relationship then enabled us to apply the cointegration method and formulate an empirical description of the paths of durable and nondurable consumption.

Using U.S. and Canadian data, we estimated the path of consumption which incorporated the effect of public consumption and solved and simulated these paths to calculate the effect on durable and nondurable private consumption of both a temporary and a permanent shock to public spending on goods and services. In addition to confirming our theoretical conjecture regarding the nature of crowding out effect, the empirical results also led to an important observation concerning the way components of private aggregate demand 
respond to a fiscal shock. We saw that in both countries evidence suggested that demand for durable goods is likely to show relatively large swings which may undermine the stability of the sector and harm the supply side ${ }^{8}$.

\footnotetext{
${ }^{8}$ Molana (1997) reports similar results for the UK.
} 


\section{References}

Akaike, H. (1973). Information theory and the extension of the maximum likelihood principle. In Proceedings of the Second International Symposium on Information Theory, eds. Petrov, B.N. and Caski, F., Budapest: Akedemiai Kiado.

Aschauer, D.A. (1985). Fiscal policy and aggregate demand, American Economic Review, 75: 117-127.

Darby, J. and Malley, J. (1996). Fiscal policy and aggregate consumption: new evidence from the United States, Scottish Journal of Political Economy, 43: 129-145.

Dickey, D. and Fuller, W.A. (1979). Distribution of the estimates for autoregressive time series with a unit root, Journal of the American Statistical Association, 74: 427-431.

Dickey, D. and Fuller, W.A. (1981). Likelihood ratio statistics for autoregressive time series with a unit root, Econometrica, 49: 1057-1072.

Feldstein, M. (1982). Government deficits and aggregate demand. Journal of Monetary Economics, 9: 1-20.

Hall, R. (1978). Stochastic implications of the life cycle permanent income hypothesis: theory and evidence, Journal of Political Economy, 86: 971-987.

Hannan, E.J. and Quinn B.G. (1979). The determination of the order of an autoregression, Journal of the Royal Statistical Society B, 41: 190-195.

Johansen, S. (1988). Statistical analysis of cointegration vectors, Journal of Economic Dynamics and Control, 12: 231-254.

Kormendi, R. (1983). Government debt, government spending and private sector behaviour, American Economic Review, 73: 994-1010.

MacKinnon, J.G. (1994). Approximate asymptotic distribution functions for unit-root and cointegration tests, Journal of Business and Economic Statistics, 12: 167-176.

Modigliani, F. and Sterling, A. (1986). Government debt, government spending and private sector behaviour: a comment, American Economic Review, 76: 1168-79.

Molana, H. (1991). The time series consumption function: error correction, random walk and the steady state, Economic Journal, 101: 382-403.

Molana, H. (1997). Consumption and fiscal policy: UK evidence from a cointegration approach on substitution between private and public spending on goods and services, Empirical Economics, 22: 63-81.

Ni, S. (1995). An empirical analysis on the substitutability between private consumption and government purchases, Journal of Monetary Economics, 36: 593-605. 
Pantula, S.G., Gonzalez-Farias, G. and Fuller, W.A. (1994). A comparison of unit-root test criteria, Journal of Business and Economic Statistics, 12: 449-459.

Schwarz, G. (1978). Estimating the dimension of a model, Annals of Statistics, 6: 461-464.

Pesaran, M.H., Shin, Y., and Smith, R.J. (1996). Structural Analysis of Vector Error Correction Models with Exogenous I(1) Variables, DAE Working Paper No. 9706, Department of Applied Econometrics, University of Cambridge.

Phillips, P.C.B. and Perron, P. (1988). Testing for a unit root in time series regression, Biometrika, 75: 335-346.

\section{Appendix for Data Sources}

\section{$\underline{\text { U.S. Data }}$}

The Private Consumption, Government Expenditure, Population and Disposable Personal Income data, 1929-96 are from the National Income and Product Accounts, U.S. Department of Commerce - Aug. 131997 release. The data is made available by the INFORUM GROUP, Department of Economics, University of Maryland, http://infourm.umd.edu/.

The Stock of Durable Goods Owned by Consumers and the Rate of Depreciation are from A. Katz and S. Herman, Improved Estimates of Fixed Reproducible Tangible Wealth, 1929-95, Survey of Current Business, U.S. Department of Commerce, 1997.

The Nominal 3-month Treasury Bill Rate, 1934-96 is from the Federal Reserve Bank of St. Louis Database http://www.stls.frb.org/fred/.

\section{Canadian Data}

The Private Consumption, Population and Disposable Personal Income data, 1926-96 are from the Canadian Socio-Economic Information System (CANSIM), "http://www.statcan.ca/".

The Stock of Durable Goods is derived by applying the perpetual inventory method to Flow of Durables using the U.S. rate of depreciation, starting in 1929.

Government Non-Defence Spending, 1930-96 is from the Department of Finance, Statistics Canada.

The Nominal 3-month Treasury Bill Rate, 1934-96 is from the Bank of Canada, Department of Monetary and Financial Analysis, "http://www.bank-banque-canada.ca/pdf/annual_page3_ page4.pdf/". 
